Contents lists available at Egyptian Knowledge Bank
Journal homepage: http://mb.journals.ekb.eg/

\title{
Endophytic fungi: A new strategy to conserve medicinal plants in Jordan
}

\section{Khawla Hasan Mohammad Alnweiri*}

Biology Department, Faculty of Science, Mu'tah University, Hashemite Kingdom of Jordan.

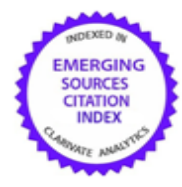

\begin{tabular}{l} 
ARTICLE II \\
\hline Article history \\
Received 19 Octo \\
Received revise \\
Accepted 25 Dece \\
Available onlin \\
@ Alnweiri 2020 \\
Corresponding Ed \\
Abdel-Azeem \\
Abo Nahas HH \\
Balbool BA \\
Keywords \\
Asteraceae \\
Lamiaceae \\
Over collection \\
Antioxidants \\
Biodiversity \\
Conventions
\end{tabular}

\section{ARTICLE INFO}

Article history

Accepted 25 December 2020

Available online 3 January 2021

Corresponding Editor:

Abdel-Azeem MA

Abo Nahas $\mathrm{HH}$

Keywords

Asteraceae

Lamiaceae

Over collection

Biodiversity

Conventions

\begin{abstract}
Jordan contains approximately 2,500 species of plants distributed throughout the Kingdom, from these species there are 485 species belonging to 99 different families are categorized as medicinal plants. Many species of plants, including those of medicinal value, are becoming threatened, endangered, rare, nearly extinct, or extinct because of misguided human activities. The primary causes for loss of medicinal plant diversity are destruction and overcollection of medicinal plants in their natural habitats. As a golden mine of bioactive molecules, endophytic fungi have been attracted the attention of researchers worldwide over the past few years because their presence benefits the host plant, and they are a source of secondary metabolites of potential interest. There are an increasing number of reports on their identification and on the production of secondary metabolites. In Jordan, endophytic fungal research is completely overlooked and until now no solid study on endophytic fungi of medicinal plants in the country has been carried by any Jordanian researchers. This review aims to shed the light on the importance of endophytic fungi, their useful products and application and how we can use them as a news strategy to conserve medicinal plants in Jordan with special reference to Asteraceae and Lamiaceae.
\end{abstract}

Published by Arab Society for Fungal Conservation

\section{Introduction}

Jordan is a small country with high geographical and ecological diversity and peoples used wild medicinal plants in treatment of various diseases since ancient times (Hudaib et al. 2008; Aldal'in et al. 2020). Jordan is characterized by the abundance of medicinal plants in respectable numbers compared to its size as a small country, and this figure of medicinal plants is because Jordan is characterized by moderate climate and geographical location, where the percentage of medicinal plants in Jordan is about $20 \%$ of the total flora of the kingdom (Abdelhalim et al. 2017).

The importance of medicinal plants lies in their potential effects on some biological activities on living organisms e.g. antidiabetic, antileukemic, antispasmodic, sedative, antimicrobial and anticancer (Oran 2014). In his study Oran (2014) and based on the World Health Organization (WHO) report mentioned that about 4000 million people in developing countries, especially Arab countries, believe in the efficacy of plant remedies and use them regularly, and as a result of the increase in population and the increase in urban sprawl, in addition to overgrazing and overcollection of plants a great the depletion of some plants with medicinal importance has been recorded.

Worldwide, medicinal plants used in pharmaceutical and pharmacological industries through isolation the active ingredients from different plant parts (Aldal'in et al. 2020), but in Jordan the extraction of medicinal plants and their

\footnotetext{
* Corresponding author

E-mail address: khawla.hasan96@gmail.com (Khawla Hasan)
} 
application in pharmaceutical industry still overlooked until now (Oran 2016).

Recently, herbalists and pharmacists have shown good interest in medicinal plants because they contain biomolecules used in the manufacture of effective medicines against incurable diseases (Jaradat 2015). Approximately 2,500 species of plants distributed throughout the Kingdom of Jordan, from these species there are 485 species belonging to 99 different families are categorized as medicinal plants (Al-Zereini et al. 2018).

Many plant taxonomists in Jordan like evaluated the biodiversity of medicinal plants in the Kingdom. AlEisawi (2015), evaluated the diversity of the medicinal plants in Mujib Biosphere Reserve. While Oran (2016) studied the medicinal plants in Al- Balqa governorate and Abdelhalim et al. (2017) surveyed their distribution and biodiversity in Al-Tafila governorate.

In Jordan, many people used medicinal plants in folk medicine to treat many diseases instead of using synthetic drugs to avoid and overcome side effects of these drugs (AlRimawi et al. 2018). Medicinal plants were selected due to their bioactive secondary metabolites such as flavonoids, phenols, phenolic glycosides, unsaturated lactones, sulphur compounds, saponins, cyanogenic glycosides and glucosinolates (Talib and Mahasneh 2010).

In this review I selected two common families namely: Asteraceae and Lamiaceae as they represent the most used families in folk medicine in Jordan. Family Asteraceae (the sunflower family) has attracted the attention of many researchers due to their content of antioxidant compounds which play an important role in biological activities such as cytotoxic and anticancer (Bader et al. 2019) (Table 1).

Lamiaceae (Labiatae) is known as lumbase nilcols in Asian countries, characterized by secondary metabolites including antibacterial, antifungal, antioxidant, antiinflammatory and antiviral because this family considered as rich source of essential oils that used in food, pharmaceutical and cosmetic industries (Mesquita et al. 2019).

Many studies conducted by Jordanian researchers on essential oils of some plants from Lamiaceae such as Mentha longifolia by Bahtiti (2015) to analyze the chemical composition of its essential oils. In some medicinal plants, as in the Ziziphora tenuior, the yield and the content of essential oils may be influenced by environmental and geographical factors, such as climate precipitation, altitude, temperature, plant competition and soil nitrogen concentration (Abu-Darwish 2016a) (Table 2).

Human exploitation of fragile plant communities and ecosystems has been occurring in recent times at an accelerating pace. In general, worldwide loss of habitat has resulted from human overpopulation, global warming, resource extraction, creeping agricultural developments and over collection. Many species of plants, including those of medicinal value, are becoming threatened, endangered, rare, nearly extinct, or extinct because of misguided human activities. The primary causes for loss of medicinal plant diversity are destruction and overcollection of medicinal plants in their natural habitats (McKenzie et al. 2009).

\section{Can endophytic fungi conserve medicinal plants?}

The term of endophyte defined as the microorganisms that inhabiting within the tissues of plant without cause any negative effects (Yu et al. 2020).

Symbiotic relationships between plants and fungal endophytes are very beneficial to the plant because endophytes defend their host plant from insects, pests and herbivores and help their hosts adapt to various stress conditions (Clay and Schardl 2002; Malinowski et al. 2006), while endophytes benefit from their hosts for nutrition, defense, and reproduction (Clay and Schardl 2002).

As mentioned by Zhao et al. (2010), during the long period of co-evolution, a friendly relationship was formed between each endophyte and its host plant. Some endophytes can produce the same or similar bioactive compounds as those originated from their host plants.

In recent decades and because the consequences that encounter the medicinal plants such as climate changes, overcollection of some plants, pollution, limited water resources and loss of habitat, an alternative had to be found to maintain these plants from extinction, thus the researchers had been focused on endophytic fungi because of their effective role in producing substances similar or the same to the substances produced by plants (Abdel-Azeem et al., 2019). Endophytic fungi recovered from harsh habitats can conserve their host plants against over collection and can be used as an alternative to medicinal plants (Abdel-Azeem et al. 2020).

One of the closet countries to Jordan is Egypt. In Egypt large number of studies carried by researchers in Suez Canal University and National Research Center on endophytic fungi in Arid Sinai. In the following paragraphs I will discuss some of these studies to attract the reader attention on how we can use metabolites of endophytic fungi in different fields.

In 2016, Abdel-Azeem et al. studied the antirheumatoid activity of secondary metabolites produced by the endophytic Chaetomium globosum recovered from Adiantum capillus-veneris from the arid Sinai.

Khalil et al. (2016) studied the effects of Chaetomium globosum and Curvularia lunata on Rheumatoid Arteritis (RA) and the results revealed that the effects of crude extracts of both taxa were similar to the effects observed from Leflunomide, the well-known drug in the treatment of RA. Although it is obvious that Leflunomide is a clinically effective drug, it is well known that it results in bone marrow 
hypocellularity; thus, it would not be a desirable therapeutic agent in RA patients.

In 2018, Abdel-Azeem et al. studied the hepatocurative effects of endophytic fungi hosted medicinal plants in SKP. During their study, 36 species belonging to 21 genera were isolated from 7 medicinal plants. Ascomycota was represented by 35 species and only 1 for Zygomycota. The dominant and most frequently isolated taxa were Aspergillus flavus and A. niger (they were omitted during our study due to their ability to produce mycotoxins), followed by Alternaria alternata, Curvularia lunata, Penicillium chrysogenum, Chaetomium globosum and Trichoderma viride.

The previously mentioned five species were surveyed for their $\mathrm{H} 2 \mathrm{O} 2$ scavenging activity. The results showed that, among the five species, Chaetomium globosum recovered from Adiantum capillus-veneris and Curvularia lunata isolated from Verbascum sinaiticum have the higher radical scavenging activity as recorded $75.31 \%$ and $73.44 \%$ respectively. So, both taxa were chosen for determination of their flavonoid and phenolic content. Chaetomium globosum and $C$. lunata recorded 92.5 and $106 \mu \mathrm{g} / \mathrm{ml}$ of total flavonoid and 3.594 and $3.172 \mathrm{mg} / \mathrm{ml}$ of total phenolic content respectively.

Depending on the results of antioxidant and biochemichal studies, Chaetomium globosum (CG) and Curvularia lunata (CL) were selected to survey their metabolites curative potentiality against paracetamol induced-liver injury in mice. Both taxa were cultivated on potato dextrose broth (PDB) medium for 15 days at $28^{\circ} \mathrm{C}$, followed by extraction with ethyl acetate (EtOAc). For each species two extracted were examined watery (W) and ethyl acteate $(\mathrm{E})$.

Abo Nahas (2019) collected the studies carried by Abdel-Azeem's team in Suez Canal University in her review titled" Endophytic fungi: A gold mine of antioxidants. This is common in medicinal plants because of its frequent use in the pharmaceutical industries as it contains the active ingredients, so it contributes to treating many diseases (Abdel-Azeem et al. 2019). A study prepared by Huang et al. (2009) identify the endophytic fungi isolated from three Artemisia species and another study on Chaetomium globosum endophytic fungus, which was isolated from Hypericum sinaicum (Selim et al. 2018).

In 2015, Abdel-Azeem et al. surveyed Egyptian endophytic fungi hosted medicinal plants in Saint Katherine Protectorate for production of some pharmaceutical and industrial enzymes.

The study that carried by Moharram et al. (2016) reported 7 endophytic fungal species and two different sterile mycelia from healthy apparent leaves of Withania somnifera then they have been examined for their Lasparaginase enzyme yielding ability. Of all isolates Alternaria alternata was the most common fungal isolates.
The results revealed that all examined isolated fungi were able to create L-asparaginase enzyme excepting Eurotium rubrum. Six isolated endophytic fungi showed elevated amount of 1-asparaginase enzyme in their filtrates of culture with $1.1 \pm 0.03-1.98 \pm 0.16$ IU range.

Salem and Abdel-Azeem (2014) surveyed anticancer metabolites produced by some endophytic mycobiota isolated from some medicinal plants in Saint Katherine Protectorate, South Sinai. Throughout their study, 75 endophytic taxa with 32 genera were isolated and identified from eight dominant plant species occupying different altitudes in Saint Katherine Protectorate. To explore the anti-cancer activity of endophytic metabolites two taxa namely Stachybotrys chartarum (4E-SCUF) and Trichothecium roseum (23A-SCUF) were selected and cultivated on potato dextrose broth (PDB) medium for 14 days at $28^{\circ} \mathrm{C}$, followed by extraction twice with ethyl acetate (EtOAc). Fungal extracts were tried in vivo against Ehrlich Ascites Carcinoma (EAC) cells in female Swiss albino mice. Parameters used to estimate the therapeutic effects of EtOAc and aqueous extracts of fungi on EAC bearing mice include: body weight gain (BWG), tumor volume (TV), median survival time (MST) and percentage increased life span (\%ILS). Moreover, their effects on some liver and kidney biochemical parameters and several tumor markers were also investigated.

Both EtOAc and aqueous extracts of $T$. roseum significantly decreased BWG and $\mathrm{TV}$, but significantly increased MST and \%ILS as 23-27 and 48-71\% respectively. Biochemically, $T$. roseum metabolite extracts did not alter liver or kidney functions, while significantly reduced the tumor markers for breast cancer (CA 15.3), ovarian cancer (CA 12.5), pancreas cancer (CA 19.9), carcinoembryonic antigen (CEA) and -fetoprotein tumor marker (AFP).

Balbool and Abdel-Azeem (2020) reported that Lasparaginase synthesized by seven strains; representing 4 different species, of all 25 endophytic fungal species which isolated and purified from a 23 plant species recovered from Protectorate of Saint Katherine, South Sinai. These positive results have enzymatic activities within the range from 44.5 \pm 1.66 to $152.58 \pm 0.63 \mathrm{Uml}^{-1}$. The maximum activity with $152.58 \mathrm{Uml}^{-1}$ was recorded for Lasiodiplodia theobromae isolated from Teucrium polium. Also L. theobromae in this study promised to be used as an alternate and dependable resource of L-asparaginase for effective cancer inhibitory agents.

Synthesis of fungal-derived silver nanoparticles (AgNPs) by endophytic fungi is being of major interest and applied recently in various fields. Abu-Elsaoud et al. (2015) aimed to green synthesis of AgNPs by some endophytic native 
Table 1 Some species of Asteraceae and their uses

\begin{tabular}{|c|c|c|c|c|c|}
\hline Scientific name & $\begin{array}{l}\text { Local } \\
\text { name }\end{array}$ & Active ingredients & $\begin{array}{l}\text { Methods } \\
\text { of use }\end{array}$ & Recommended uses & References \\
\hline Varthemia iphionoides & Ktaile & $\begin{array}{l}\text { Eudesmane sesquiterpene. } \\
\text { Flavonoids: jaceidine, } \\
\text { kumatakenine, } \\
\text { xanthomicrol, seven 3- } \\
\text { methoxyflavones. Essential } \\
\text { oil }\end{array}$ & Decoction & $\begin{array}{l}\text { Women sterility, female } \\
\text { fertilization, eye infection, } \\
\text { antispasmodic antiinflammatory, } \\
\text { diabetes. } \\
\text { antioxidative effects. Cytotoxic } \\
\text { effect on human leukemia }\end{array}$ & Afifi,2013 \\
\hline Inula viscosa & Taioon & $\begin{array}{l}\text { flavonoids, terpenoids, } \\
\text { phenolics and coumarins. }\end{array}$ & Decoction & $\begin{array}{l}\text { Anthelmintic, for lung cancer, } \\
\text { muscle relaxant, Wound and ulcer } \\
\text { treatment, bleeding joints pain, } \\
\text { respiratory tract infections, blood } \\
\text { pressure, diabetes, Back ache, gum } \\
\text { disorder and skin fungi treatment }\end{array}$ & $\begin{array}{l}\text { Talib and } \\
\text { Mahasneh, } \\
(2010), \\
\text { Abuhamdah } \\
\text { et al. (2013) }\end{array}$ \\
\hline Artemisia herba-alba & Sheih & $\begin{array}{l}\text { Flavonoids. Main essential } \\
\text { oil components: } \beta \text {-thujone } \\
\text { and } \alpha \text {-thujone, } 1,8 \text {-cineole, } \\
\text { camphor, chrysanthenone, } \\
\text { trans-sabinyl acetate, trans- } \\
\text { pinocarveol, and borneol }\end{array}$ & Infusion & $\begin{array}{l}\text { Wound healing, anthelmintic, } \\
\text { eczema, colic, } \\
\text { antidiabetic, headache }\end{array}$ & $\begin{array}{l}\text { Afifi-Yazar } \\
\text { et al. (2011) }\end{array}$ \\
\hline Matricaria aurea & Baboonej & $\begin{array}{l}\text { quercetin, coumarins: } \\
\text { umbelliferone, caffeic acid, } \\
\text { apigenin-7-O-glucoside, } \\
\text { and naringenin }\end{array}$ & Infusion & $\begin{array}{l}\text { Antispasmodic, antipyretic, } \\
\text { anticough, antinfluenza, antiasthma } \\
\text { and antiflatulence }\end{array}$ & $\begin{array}{l}\text { Hudaib et al. } \\
\text { (2008), Khan } \\
\text { et al. (2015) }\end{array}$ \\
\hline Achillea fragrantissima & Kaisoom & $\begin{array}{l}\text { Flavonoids. Essential oil } \\
\text { (santolina alcohol, } \\
\text { artemisia alcohol, artemisia } \\
\text { ketone, cis-thujone and } \\
\text { trans-thujone, 1,8-cineole, } \\
\text { fragranol, fragranyl acetate } \\
\text { and terpin-4-ol) }\end{array}$ & Infusion & $\begin{array}{c}\text { Headache, calmative, anthelmintic, } \\
\text { carminative, cough, colic, } \\
\text { antidiabetic }\end{array}$ & $\begin{array}{l}\text { Afifi, (2013), } \\
\text { Abdelhalim } \\
\text { et al. (2017) }\end{array}$ \\
\hline Cichorium intybus & Hindba & $\begin{array}{l}\text { Anthocyanins. } \\
\text { Sesquiterpene lactones of } \\
\text { guaiane and germacrane } \\
\text { type. Lactucin and } \\
\text { lactucopicrin. Quercetin. } \\
\text { Polyphenols. Flavonoids. } \\
\text { Tannins, chlorogenic acid } \\
\text { along with caffeic acid } \\
\text { derivatives }\end{array}$ & $\begin{array}{l}\text { Fresh } \\
\text { plant parts } \\
\text { are eaten }\end{array}$ & $\begin{array}{l}\text { Internal hemorrhage, sedative in } \\
\text { typhoid }\end{array}$ & $\begin{array}{l}\text { Hudaib et al. } \\
(2008) \text {, } \\
\text { Street et al. } \\
(2013)\end{array}$ \\
\hline Gundelia tournefortii & Acub & 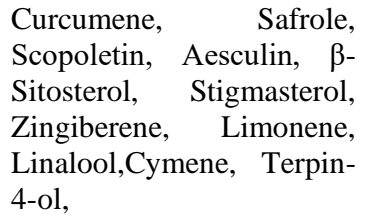 & $\begin{array}{l}\text { Fresh or } \\
\text { Cooked }\end{array}$ & $\begin{array}{l}\text { Used for the treatment of chest pain, } \\
\text { heart stroke, diabetes, Anemia and } \\
\text { to treatment liver diseases }\end{array}$ & $\begin{array}{l}\text { Asadi- } \\
\text { Samani et al. } \\
(2013)\end{array}$ \\
\hline Artemisia Judaica & Beithran & $\begin{array}{l}\text { piperitone, camphor, ethyl } \\
\text { cinnamate, } \\
\text { Chrysanthenone, } \\
\text { Piperitenone oxide. }\end{array}$ & $\begin{array}{l}\text { drenched } \\
\text { or boiled }\end{array}$ & $\begin{array}{l}\text { treatment of stomach ache, heart } \\
\text { diseases, sexual weakness, diabetes, } \\
\text { gastro-intestinal disorders and } \\
\text { external wounding }\end{array}$ & $\begin{array}{l}\text { Abu- } \\
\text { Darwish et } \\
\text { al. (2016a) }\end{array}$ \\
\hline
\end{tabular}


Table 2 Some taxa of Lamiaceae and their uses

\begin{tabular}{|c|c|c|c|c|c|}
\hline Scientific name & Local name & Active ingredients & Methods of use & Recommended uses & References \\
\hline Rosmarinus officinalis & Hasa alban & $\begin{array}{l}\text { Flavonoids: quercetin. } \\
\text { Phenolic: gallic acid. } \\
\text { carnosol, carnosic } \\
\text { acid, rosmarinic acid, } \\
\text { ursolic acid, and } \\
\text { caffeic acid }\end{array}$ & Infusion & $\begin{array}{l}\text { antioxidant, antimicrobial, } \\
\text { antidiabetic, cancer } \\
\text { chemopreventive, choleretic, } \\
\text { and a stimulant and mild } \\
\text { analgesic, and it has been } \\
\text { considered effective for } \\
\text { treating headaches, } \\
\text { inflammatory diseases. }\end{array}$ & $\begin{array}{l}\text { Al- } \\
\text { Kharabsheh } \\
\text { et al. (2017) }\end{array}$ \\
\hline Mentha longifolia & Nana & $\begin{array}{l}\text { Pulegone, } \\
\text { isomenthone, } \\
\text { Piperitone oxid, } \\
\text { Pulespenone, } \alpha \text { - } \\
\text { pipene Piperitenone } \\
\text { oxide, } \beta \text {-Pinene, } \\
\text { Cyclohexanone, 3- } \\
\text { vinyl-3-methyl, and } \\
\text { 1, 8-Cineole }\end{array}$ & Infusion & $\begin{array}{l}\text { used for respiratory ailments, } \\
\text { coughs, colds, stomach } \\
\text { cramps, asthma, flatulence, } \\
\text { indigestion and headaches. }\end{array}$ & $\begin{array}{l}\text { Bahtiti } \\
(2015)\end{array}$ \\
\hline Teucrium polium & Ja'adeh & $\begin{array}{l}\text { 8-cedren-13-ol, } \quad \beta \text { - } \\
\text { caryophllene, } \\
\text { sabinene } \\
\text { germacrene D }\end{array}$ & Infusion & $\begin{array}{l}\text { anticancer, antioxidant, } \\
\text { hepatoprotective, } \\
\text { hypoglycemic, anti- } \\
\text { inflammatory, hypolipidemic, } \\
\text { antifungal, antiviral, } \\
\text { antibacterial, antispasmodic }\end{array}$ & $\begin{array}{l}\text { Jaradat } \\
(2015)\end{array}$ \\
\hline Melissa officinalis & lemon balm & $\begin{array}{l}\text { Cyanuric Acid. 3- } \\
\text { OH-Tetradecenedioic } \\
\text { Acid. } \\
\text { 3- OH-Dodecenedioic } \\
\text { Acid. Glucuronic-1- } \\
\text { Pent. Phenobarbital. } \\
\alpha-\text { D-Glucopyranose. } \\
\text { Palmitic acid }\end{array}$ & Infusion & $\begin{array}{l}\text { depression, nervousness and } \\
\text { stress induced headaches, } \\
\text { antiseptic, calmative, } \\
\text { antitumor activity, anti-HIV } \\
\text { activity }\end{array}$ & $\begin{array}{l}\text { Bayat et al. } \\
\text { (2012), } \\
\text { Aldal'in, } \\
\text { (2018). }\end{array}$ \\
\hline Salvia officinalis & Meriamia & $\begin{array}{l}\text { 3-OH-Dodecenedioic } \\
\text { acid, unsaturated 3- } \\
\text { OH-sebaceous, } \\
\text { palmitic acid, } \\
\text { 1,3- Propanediol, } \\
\text { Isobutyric acid, L- } \\
\text { ascorbic acid, silane, } \\
\text { D-Glucuronic acid. }\end{array}$ & $\begin{array}{l}\text { Decoction, } \\
\text { infusion }\end{array}$ & $\begin{array}{l}\text { treatment of different kinds of } \\
\text { disorders. These disorders like } \\
\text { dizziness, tremor, seizure, } \\
\text { paralysis, ulcers, } \\
\text { hyperglycemia, inflammation, } \\
\text { gout, rheumatism and diarrhea }\end{array}$ & $\begin{array}{l}\text { Abdelhalim } \\
\text { et al. (2017), } \\
\text { Aldal'in et al. } \\
\text { (2020) }\end{array}$ \\
\hline Thymus vulgaris & Zaatar & $\begin{array}{l}\text { alkaloids, } \\
\text { carbohydrates and } \\
\text { glycosides, resins, } \\
\text { flavenoids, saponins, } \\
\text { tannins, unsaturated } \\
\text { sterols and triterpenes }\end{array}$ & Infusion & $\begin{array}{l}\text { antibacterial, antiviral, anti- } \\
\text { fungal, potent } \\
\text { antihypertensive. } \\
\text { inflammatory, antispasmodic } \\
\text { and analgesic agent. }\end{array}$ & $\begin{array}{l}\text { Shaban et al. } \\
(2015)\end{array}$ \\
\hline Ziziphora tenuior & Zizfran & $\begin{array}{l}\text { Essential oil consists } \\
\text { of: } \\
\text { Pulegone. } \\
\text { Isomenthone. } \\
\text { p-menth-3-en-8-ol. } \\
\text { 8- hydroxymenthone. } \\
\text { Isomenthol. } \\
\text { isomenthyl acetate. } \\
\text { Spathuleno. } \\
\text { Limonene. } \\
\text { cineole. } \\
\text { caryophyllene oxide. } \\
\text { viridiflorol and the } \\
\text { diterpene manool }\end{array}$ & & $\begin{array}{l}\text { Treatment of cough, stomach } \\
\text { ache, fever, dysenteryuterus } \\
\text { infection, } \\
\text { menstruation and gainful } \\
\text { inflammation. }\end{array}$ & $\begin{array}{l}\text { Abu- } \\
\text { Darwish et } \\
\text { al. }(2016 b)\end{array}$ \\
\hline
\end{tabular}


taxa isolated from six medicinal plants from arid South Sinai and optimizing production conditions combined with photostimulation. Thirteen species out of twenty-two entophytic fungi were screened for production of AgNPs.

Reaction conditions such as silver nitrate concentration, $\mathrm{pH}$, temperature and efficiency of photostimulation using monochromatic red polarized light and UV radiations were optimized and assed for high production of AgNPs. High concentrations of AgNPs were produced by Chaetomium globosum and Trichoderma viride recovered from Tanacetum sinaicum and Chiliadenus montanus respectively. Both fungi showed significantly different response to photostimulation by either red polarized or red LED light. T. viride showed a promising results and significant increase in AgNPs production after photostimulation by monochromatic red polarized light. Application of monochromatic red polarized light in the field of bionanotechnology for enhancing green synthesis of AgNPs would be recommended.

During continuous bioprospecting of endophytic fungi in Saint Katherine Protectorate carried by Abdel-Azeem et a. (2020), fungal endobionts hosted four wild medicinal plants were isolated and surveyed for their capability to green synthesize AgNPs. Trichoderma atroviride hosted in Chiliadenus montanus, the most potent taxon for production was selected. The mycosynthesized AgNPs were characterized using UV-vis (UV-vis), Raman spectroscopy, X-ray diffraction (XRD) and high-resolution transmission electron microscopy (HRTEM). The antibacterial and antifungal efficacy of the mycosynthesized AgNPs was studied against phyto and human pathogenic bacteria (Staphylococcus aureus, Bacillus cereus, Escherichia coli, Klebsiella pneumoniae, Shigella flexneri, and Salmonella typhimurium), yeast (Candida albicans) and filamentous fungi (Aspergillus brasiliensis, A. niger and Fusarium oxysporum).

Many secondary metabolites are synthesized by endophytic fungi, such as flavonoids, terpenoids, steroids, phenol, phenyl propanoids, quinines, indol derivatives, amines, alkaloids, amides, pyrrolizidines, sesquiterpenes, diterpenes, lignans, derivatives of isocoumarin, peptides, phenolic acids, chlorinated metabolites, aliphatic compounds, etc. (Abdel-Azeem et al., 2019; Abdel-Azeem et al., 2020). Such secondary metabolites are energy consuming compounds, so that, depending on specific requirements, endophytes may increase/decrease their development, such as competition with other microorganisms or communication and defense of host plants (Bamisile et al. 2018).

Plants have contributed over 7,000 compounds to the pharmaceutical industry in developed countries, includin $\mathrm{g}$ those used in heart drugs, laxatives, anti-cancer, hormones, contraceptives, analgesics, antimalarial, antidiabetic, antimicrobial, antiviral, antibiotics, diuretics, etc. (Kaul et al., 2012).

Endophytes can play several significant advantageous roles in host plant. These benefits including: 1- Increasing the resistance of plant to pathogens and herbivores (biotic stress) (Yao et al. 2017) and abiotic stress by producing bioactive compounds as alkaloids, diterpenes, flavonoids, and isoflavonoids (Rodriguez et al., 2009). Fungal endophytes act as a biocontrol agent in which the plant's immune response is strengthened because the plants lack an immune response to certain pathogens. (Rajamanikyam et al. 2017). 2- Promoting the growth of host plants by enhancing the secretion of hormones (e.g. indole-3-acetic acid, cytokinins), and activation of some enzymes (Chen and Guo 2005). 3- Promote the accumulation of secondary metabolites of medicinal plants or enhancement the formation and accumulation of these compounds that were only produced by host plants. These compounds which result from endophytic fungi can be exploited and their use in medicinal industries for treatment the disease instead of use plants and this contribute to conserve plant from extinction (Tejesvi et al. 2007; Kaul et al. 2012).

Taxol or paclitaxel are produced from Taxus brevifolia trees, where this compound plays an important role as anticancer agent. Taxol are concentrating in Taxus brevifolia in a range about $0.001-0.05 \%$ meaning that the three trees are required to produce $1 \mathrm{~g}$, while every cancer patient requires about $2.5 \mathrm{~g}$. So, the rapid loss of this plant will be occurred, endophytic fungus Taxomyces andreanae which isolate from Taxus brevifolia use as an alternative way to extraction taxol without loss of Taxus brevifolia trees (Stierle et al. 1995; Malik et al. 2011; Kaul et al. 2012).

The Jordan kingdom lacks the studies concerning endophytic fungi hosted medicinal plants and only one study conducted on wheat plant was carried by AlKhawaldeh et al (2020). In their study they isolated and classified cultivable fungal endophytes of wheat collected from various regions of Jordan and the second aim is by performing in vitro seed tests and checking the germination performance of seeds with and without endophytes, the endophytic properties are tested. Also, their work showed that certain environmental fluctuations of the host plant may affect the distribution of endophytic fungi, including temperature, humidity, illumination, geographic position and soil nutrition levels in addition to their use in the determination of the types and quantities of secondary metabolites of the host plants in accordance with Jia et al. (2016).

The role of endophytic fungi in conservation of their hosts already studied by Abdel-Azeem et al. (2019). In addition, endophytes enhance the ability of plants to overcome stresses by producing chemical compounds (Zhao et al. 2010). 


\section{Conclusions}

This review addresses to highlight on some medicinal plants in the Hashemite Kingdom of Jordan and its content of chemical compounds which contribute to the treatment of many diseases, where the Jordanian people depend on these plants since ancient times in folk medicine, as these chemical compounds (active ingredients) use in pharmaceutical and pharmacological industries through its isolation from plant.

Medicinal plants take $20 \%$ of the total flora in Jordan, this percentage are vulnerable to depletion and extinction due to overcollection of people, overgrazing and the increase in urban sprawl. In this review, we shed light on a strategy to preserve these plants from extinction especially from uncontrolled collection of people and finding an alternative to them is equally important and benefit.

Endophytic fungi are the proposed new strategy that we discussed in this review to preserve plants where these fungi producing substances similar or the same to the substances produced by plants, increasing the resistance of plant to biotic and abiotic stresses, so the researchers use as an alternative to the plant in pharmaceutical industries and another.

As discussed before in this review, many studies in many countries showed the importance of endophytic fungi in conservation of plant and its active role in producing active substance. Consequently, these studies deserve the attention of researchers in the Hashemite Kingdom of Jordan, as it opens a new portal to study this type of mycobiota from which the kingdom can find alternatives to over collection of medicinal plants and apply a new strategy in conservation of plants.

\section{Acknowledgements}

I would like to thank authors of all literatures used in this work.

\section{Funding}

No funding was used to conduct this research.

\section{References}

Abdel-Azeem AM, Zaki SM, Khalil WF, Makhlouf NA, Farghaly LM (2016) Anti-rheumatoid activity of secondary metabolites produced by endophytic Chaetomium globosum. Front Micro 7: 1477.

Abdel-Azeem AM, Abdel-Azeem MA, Khalil WF (2019) Endophytic fungi as a new source of antirheumatoid metabolites. In Bioactive Food as dietary interventions for arthritis and related inflammatory diseases (pp. 355-384). Academic Press.

Abdel-Azeem AM, Omran AM and Abdel Zaher MR (2018) Evaluation of the curative probability of bioactive metabolites from endophytic fungi isolated from some medicinal plants against paracetamol - induced liver injury in mice, Lambert academic publishing. ISBN: 978-613-9-89820-6.

Abdel-Azeem A, Nada AA, O'donovan A, Thakur VK, Elkelish A (2020) Mycogenic Silver Nanoparticles From Endophytic Trichoderma atroviride with Antimicrobial Activity. J Ren Mat 8(2): 171.

Abdel-Azeem MA, Abdel-Aziz DM, Salem FM, AbdelAzeem AM (2015) Surveying of Egyptian endophytic fungi for production of some pharmaceutical and industrial enzymes. 1st Scientific Forum for Student Research, Faculty of Science, Suez Canal University, Ismailia, Egypt, 5 October 2015, Abstract book 24.

Abdelhalim A, Aburjai T, Hanrahan J, Abdel-Halim H. (2017) Medicinal plants used by traditional healers in Jordan, the Tafila region. Pharma Mag. 13(Suppl 1), S95.

Abo Nahas HH (2019) Endophytic fungi: A gold mine of antioxidants. Microb Biosyst 4:58-79.

Abu-Darwish MS, Cabral C, Gonçalves MJ, Cavaleiro C, Cruz MT, Zulfiqar A, Salgueiro L (2016 a) Chemical composition and biological activities of Artemisia judaica essential oil from southern desert of Jordan. J. Ethnopharmacol 191: 161-168.

Abu-Darwish MS, Cabral C, Gonçalves MJ, Cavaleiro C, Cruz MT, Paoli M, Salgueiro L (2016b) Ziziphora tenuior L. essential oil from Dana Biosphere Reserve (Southern Jordan); Chemical characterization and assessment of biological activities. J. Ethnopharmacol 194: 963-970.

AbuElsaoud AM, Abdel-Azeem AM, Shaker MA, Hassan SSM (2015) Biosynthesis, optimisation and Photostimulation of $\alpha \mathrm{NADPH}$ dependent nitrate Reductase mediated silver nanoparticles by Egyptian endophytic fungi. Adv Env Biol 9(24): 259-269.

Abuhamdah S, Abuhamdah R, Al-Olimat S, Chazot P (2013) Phytochemical investigations and antibacterial activity of selected medicinal plants from Jordan. Eur J Med Pl 394-404.

Afifi FU, Kasabri V (2013) Pharmacological and phytochemical appraisal of selected medicinal plants from Jordan with claimed antidiabetic activities. Sci Pharm 81(4): 889-932.

Afifi-Yazar FU, Kasabri V, Abu-Dahab R (2011) Medicinal plants from Jordan in the treatment of diabetes: traditional uses vs. in vitro and in vivo evaluationspart 2. Planta Med 77(11): 1210-1220.

Aldal'in, HK (2018) Phytochemical analysis of methanolic extract of Jordanian Melissa officinalis L. Int J Bio 10(4):58-62.

Aldal'in HK, Wedian F, Al-Mazaideh GM, Salman HA, AlRimawi F, Alakhras F, Al-Nadaf AH (2020) Comparative Analysis of Phytochemical 
Composition of Ethanolic Extract of Jordanian Silvia officinalis. Pak J Biol Sci 23 (8):989-994.

Al-Kharabsheh S, Al-Dabbas M, Ghazzawi H, Zatimeh A, Abulaila K (2017) Antioxidant activity and $\alpha$ amylase inhibitory effect of selected medicinal plants grown in Jordan: an in-vitro study. J Arab Soc Med Res 12(1): 19.

Al-Khawaldeh MM, Araj SE, Alananbeh KM, Al Antary TM (2020) Wheat cultivable fungal endophytes in Jordan. Fres Env Bull 29(2): 1229-1240.

Al-Rimawi F, Alakhras F, Al-Zereini WA, Aldal'in H K, Abu-Lafi S, Al-Mazaideh GM (2018) HPLC Analysis of Chemical Composition of Selected Jordanian Medicinal Plants and their Bioactive Properties. Orient J Chem 34(5): 2397-2403.

Al-Zereini WA, Al-Rimawi F, Abu-Lafi S, ALakhras F, Al-Mazaideh GM, Salman HJA, Jamhour RM (2018) Identification and Antibacterial Evaluation of Selected Jordanian Medicinal Plants. Orient J Chem 34:(5).

Alzweiri M, Al Sarhan A, Mansi K, Hudaib M, Aburjai T (2011). Ethnopharmacological survey of medicinal herbs in Jordan, the Northern Badia region. J Ethnopharm 137(1): 27-35.

Asadi-Samani M, Rafieian-Kopaei M, Azimi N (2013) Gundelia: a systematic review of medicinal and molecular perspective. Pak J Biol Sci 16(21), 12381247.

Bader A, Abdallah QM, Abdelhady MI, De Tommasi N, Malafronte N, Shaheen U, Cotugno R (2019) Cytotoxicity of Some Plants of the Asteraceae Family: Antiproliferative Activity of Psiadia punctulata Root Sesquiterpenes. Rec. Nat. Prod 13: 307-315.

Bahtiti NHA (2015) Biological activities of the methanol extract of cultivated Jordanian fresh and dried mint species (Mentha Longifolia). Int J Res Stud Biosc 3(1): 205-10.

Balbool BA, Abdel-Azeem AM (2020) Diversity of the culturable endophytic fungi producing Lasparaginase in arid Sinai, Egypt. Italian J Mycol 49: 8-24.

Bamisile BS, Dash CK, Akutse KS, Keppanan R, Wang L (2018) Fungal Endophytes: Beyond Herbivore Management. Front Microbiol. 23 (9):544. doi: 10.3389/fmicb.2018.00544. PMID: 29628919; PMCID: PMC5876286.

Bayat M, Tameh AA, Ghahremani MH, Akbari M, Mehr SE, Khanavi M, Hassanzadeh G (2012) Neuroprotective properties of Melissa officinalis after hypoxic-ischemic injury both in vitro and in vivo. DARU J Pharm Sci 20(1): 42.

Caruso G, Abdelhamid MT, Kalisz A, Sekara A (2020) Linking endophytic fungi to medicinal plants therapeutic activity. A case study on Asteraceae. Agriculture 10(7): 286.

Chen XM, Guo SX (2005). Effects of four species of endophytic fungi on the growth and polysaccharide and alkaloid contents of Dendrobium nobile. China J Chin Mat Med 30(4): 253-257.

Clay K, Schardl C (2002) Evolutionary origins and ecological consequences of endophyte symbiosis with grasses. Amer Natur 160(S4): S99-S127.

Hudaib M, Mohammad M, Bustanji Y, Tayyem R, Yousef M, Abuirjeie M, Aburjai T (2008) Ethnopharmacological survey of medicinal plants in Jordan, Mujib Nature Reserve and surrounding area. J Ethnopharm 120(1): 63-71.

Huang WY, Cai YZ, Surveswaran S, Hyde KD, Corke H, Sun M (2009). Molecular phylogenetic identification of endophytic fungi isolated from three Artemisia species. Fungal Divers. 36: 69-88.

Jaradat NA (2015) Review of the taxonomy, ethnobotany, phytochemistry, phytotherapy and phytotoxicity of germander plant (Teucrium polium L.). Medicine 3: 4.

Jia M, Chen L, Xin HL, Zheng CJ, Rahman K, Han T, Qin LP (2016) A friendly relationship between endophytic fungi and medicinal plants: a systematic review. Front Micro 7: 906.

Kaul S, Gupta S, Ahmed M, Dhar MK (2012). Endophytic fungi from medicinal plants: a treasure hunt for bioactive metabolites. Phytochem Rev: 11(4): 487505.

Khalil WF, Abdel-Azeem AM, Blanchette RA, Hefny MA, Saleh SY, Ibrahim ME (2016) Bioprospecting and conservation of Egyptian endophytic mycobiota: Taxa producing anti-inflammatory metabolites and their effects on rheumatoid arthritis' rat model. The First International Conference on Fungal Conservation in the Middle East and North of Africa, Ismailia, Egypt, 18-20 October 2016. Abstract book: 38-39.

Khan M, Abdullah M, Mahmood A, Al-Mayouf AM, Alkhathlan HZ (2019) Evaluation of Matricaria aurea extracts as effective anti-corrosive agent for mild steel in $1.0 \mathrm{M} \mathrm{HCl}$ and isolation of their active ingredients. Sustainability 11(24): 7174.

Malik S, Cusidó RM, Mirjalili MH, Moyano E, Palazón J, Bonfill M (2011). Production of the anticancer drug taxol in Taxus baccata suspension cultures: a review. Pro Biochem 46(1): 23-34.

Malinowski DP, Belesky DP (2006) Ecological importance of Neotyphodium spp. grass endophytes in agroecosystems. Grass Sci 52(1): 1-14.

McKenzie M, Kirakosyan A, Kaufman PB (2009) Risks Associated with Overcollection of Medicinal Plants in Natural Habitats. In: Recent Advances in Plant 
Biotechnology. Springer, Boston, MA. https://doi.org/10.1007/978-1-4419-0194-1_15

Mesquita LSSD, Luz TRSA, Mesquita JWCD, Coutinho D F, Amaral FMMD, Ribeiro MNDS, Malik S (2019) Exploring the anticancer properties of essential oils from family Lamiaceae. Food Rev Int 35(2): 105131.

Moharram AM, Zohri AA, Seddek NH (2015) Production of Kojic acid by endophytic fungi isolated from medicinal plants in Egypt. Int Inven $\mathbf{J}$ Bioch Bioinfor 3 (3): 28-31.

Oran SA (2014) The status of medicinal plants in Jordan. J Agr Sci Tech A: 4(6A).

Oran SA (2016) Plant diversity of Al-Balqa Governorate, Jordan. Int J Biodiv Cons 8(5): 93-104.

Oran SA, Al-Eisawi D (2015) Ethnobotanical survey of the medicinal plants in the central mountains (NorthSouth) in Jordan. J Biodiv Env Sci 6(3): 381-400.

Rahman AHMM, Alam MS, Khan SK, Ahmed F, Islam AKMR, Rahman MM (2008) Taxonomic studies on the family Asteraceae (Compositae) of the Rajshahi division. Res J Agri Bio Sci 4(2): 134-140.

Rajamanikyam M, Vadlapudi V, Upadhyayula SM (2017) Endophytic fungi as novel resources of natural therapeutics. Braz Arch Biol Technol 60.

Rodriguez RJ, White Jr JF, Arnold AE, Redman ARA (2009). Fungal endophytes: diversity and functional roles. New phytologist 182(2), 314-330.

Salem FM, Abdel-Azeem AM (2014) Screening of anticancer metabolites produced by endophytic fungi. Saarbrücken: LAP LAMBERT Academic Publishing.

Selim KA, Elkhateeb WA, Tawila AM, El-Beih AA, Abdel-Rahman TM, El-Diwany AI, Ahmed EF (2018) Antiviral and antioxidant potential of fungal endophytes of Egyptian medicinal plants. Fermentation 4(3): 49.

Shaban NS, Tohamy MA, El-Banna HA, Abeer MR, ElGendy AA, Asmaa O (2015) Phytochemical and pharmacological studies of ethanolic extract of Thymus vulgaris. World J Pharm Pharm Sci: 4-10.

Stierle A, Strobel G, Stierle D, Grothaus P, Bignami G (1995) The search for a taxol-producing microorganism among the endophytic fungi of the Pacific yew, Taxus brevifolia. J Nat Prod 58(9): 1315-1324.

Street RA, Sidana J, Prinsloo G (2013) Cichorium intybus: Traditional uses, phytochemistry, pharmacology, and toxicology. Evid Based Complement Alternat Med. doi: 10.1155/2013/579319.

Talib WH, Mahasneh AM (2010) Antimicrobial, cytotoxicity and phytochemical screening of Jordanian plants used in traditional medicine. Molecules 15(3): 1811-1824.
Tejesvi MV, Nalini MS, Mahesh B, Prakash HS, Kini KR, Shetty HS, Subbiah V (2007) New hopes from endophytic fungal secondary metabolites. Bol Soc Quím Méx, 1(1): 19-26.

Yao YQ, Lan F, Qiao YM, Wei JG, Huang RS, Li LB (2017) Endophytic fungi harbored in the root of Sophora tonkinensis Gapnep: Diversity and biocontrol potential against phytopathogens. Microbiology Open 6(3): e00437.

Yu M, Chen JC, Qu JZ, Liu F, Zhou M, Ma YM, Yang MZ (2020) Exposure to endophytic fungi quantitatively and compositionally alters anthocyanins in grape cells. Plant Phys Bioch 149: 144-152.

Zhao J, Zhou L, Wang J, Shan T, Zhong L, Liu X, Gao X (2010) Endophytic fungi for producing bioactive compounds originally from their host plants. Curr Res, Technol Educ Trop Appl Microbiol Microbial Biotechnol, 1: 567-576. 